\title{
Seasonal variation in bacterial heavy metal biosorption in water samples from Eziama river near soap and brewery industries and the environmental health implications
}

\author{
${ }_{1,2}^{*}$ I. Kanu, ${ }^{2}$ O. K. Achi, ${ }^{2}$ O. U. Ezeronye, ${ }^{3}$ E. C. Anyanwu \\ ${ }^{1}$ Department of Microbiology, Abia State University, Abia State, Nigeria \\ ${ }^{2}$ Department of Industrial Microbiology, The Michael Okpara Federal University of Agriculture, Umudike, Umuahia, \\ Abia State, Nigeria \\ ${ }^{3}$ Department of Chemistry, Environmental Toxicology Program, Texas Southern University, Houston Texas, USA
}

Received 15 November 2005;

revised 7 December 2005;

accepted 1 February 2006

available online 18 April 2006

\begin{abstract}
Seasonal variation in bacterial heavy metals biosorption from soap and brewery industrial effluent samples from Eziama River in Abia State were analyzed for Pb, Hg, Fe, Zn, As, and Mn, using atomic absorption spectrophotometry. Bioaccumulation of the metals by bacteria showed the following trend $>\mathrm{Fe}>\mathrm{Zn}>\mathrm{As}>\mathrm{Pb}>\mathrm{Mn}$ (Rainy Season) and $\mathrm{Zn}>\mathrm{Fe}>\mathrm{Mn}>\mathrm{As}>\mathrm{Hg}>\mathrm{Pb}$ (Dry season). Statistical analysis using of variance (ANOVA) showed significant differences in concentrations of $\mathrm{Pb}, \mathrm{Hg}$, Fe, $\mathrm{Zn}$, As, and $\mathrm{Mn}$ level between the sampling zones at Eziama River. Seasonal changes in heavy metal concentrations, showed increases in $\mathrm{Pb}$, Fe, and As from $1.32 \times 10^{5} \mathrm{mg} /$ $\mathrm{L}$ in the rainy season to $1.42 \times 10^{5} \mathrm{mg} / \mathrm{L}$ in the dry season. Fe increased from $40.35 \times 10^{5} \mathrm{mg} / \mathrm{L}$ to $42.1 \times 10^{5} \mathrm{mg} / \mathrm{L}$, while As increased from 2.32 to $2.48 \times 10^{5} \mathrm{mg} / \mathrm{L}$ with a net increases of +56 and $+69 \times 10^{5} \mathrm{mg} / \mathrm{L}$ respectively. However, $\mathrm{Hg}$, $\mathrm{Zn}$, and $\mathrm{Mn}$ concentrations decreased in the rainy season from $40.54 \times 10^{5} \mathrm{mg} / \mathrm{L}$ to $39.24 \times 10^{5} \mathrm{mg} / \mathrm{L}, 1.65$ to $0.62 \times$ $10^{5} \mathrm{mg} / \mathrm{L}$ respectively.
\end{abstract}

Key words: Industrial effluent, water contamination, heavy metals, health effects

*Corresponding Author, E-mail: ijay2001kay@yahoo.com

\section{INTRODUCTION}

Industrial effluent characteristics provide basic information about the integrity of the aquatic habitat within such rivers and streams into which they are discharged. Most of these effluents pose inestimable harm to which the microbial entity is the most adversely affected (Dallas, 2004; Barnes,). Most of the industrial effluents are shown to contain significant concentrations of inorganic chemicals which affect not only the normal $\mathrm{pH}$ values but also lead to the hardness of the water. These aquatic environments may put some components of the habitat on a disadvantaged position. Industrial effluents from soap manufacturing industries are known to contain complex chemicals most of which are very toxic and are capable of destroying the microbial habitats in a serious adverse way. For example, el-Gohary, et al., (1987) presented the wastewater management of an industrial complex, which produces different products, i.e. soap, perfume extract, macaroni, jam and juices. A continuous monitoring programme effluents and characterization of the composite wastewater from both soap and brewery manufacturing processes indicated that the waste was highly contaminated with organic compounds as indicated by COD and BOD values. Moreover, effluent from the soap manufacturing plant contains significant concentrations of oil and grease amounting to $563 \mathrm{mg}$ l-1. Soap manufacturing effluent and the combined wastes discharged from the whole industrial complex were subjected to different treatment processes, namely dissolved air flotation, chemical coagulationsedimentation, and biological treatment via a completely mixed activated sludge process (Agedengbe, et al., 2003). The purpose of this present study is mainly to determine the seasonal variation in heavy metal biosorption by bacteria isolated from Eziama River near Soap and Brewery Industries in Aba, Abia State Nigeria and to discuss the overall environmental Health implications. 


\section{MATERIALS AND METHODS}

Sampling location and background

The industrial effluent water samples for this analysis were obtained from selected representative areas of the Eziama River directly affected by the Soap and Brewery industries discharges. The sampling area within the Eziama River and the sampling point stretches from the Okpunumuobo end to the waterside at Ogbor Hill in Aba metropolis. This particular river runs across to Cross River State where it empties with its creek into the Atlantic ocean .The river is located at Latitude $05^{\circ}$ $29 \mathrm{~N}$, Longitude $07^{\circ} 33 \mathrm{E}$. with an Altitude of 122 meters above mean sea level.

\section{Equipment background}

Atomic absorption spectrophotometry provides accurate quantitative analyses for metals in water, sediments, soils or rocks. Atomic absorption units have four basic parts: interchangeable lamps that emit light with element-specific wavelengths, a sample aspirator, a flame or furnace apparatus for volatilizing the sample, and a photon detector. In order to analyze for any given element, a lamp is chosen that produces a wavelength of light that is absorbed by that element. Sample solutions are aspirated into the flame. If any ions of the given element are present in the flame, they will absorb light produced by the lamp before it reaches the detector. The amount of light absorbed depends on the amount of the element present in the sample. Absorbance values for unknown samples are compared to calibration curves prepared by running known samples (Alloway and Ayres, 1997).

\section{The equipment concept}

The equipment system is a microprocessor-controlled double beam spectrophotometer with a graphite furnace attachment for flameless analysis. AAS techniques are used in the effluent water sample analysis. The use of these techniques in environmental pollution studies (especially in water analysis) has received wide acceptance among researchers because of their speed, precision and simplicity of operation. Secondly, because the intensity of emission is linear and is not attenuated; thirdly, because of their freedom from matrix effects. Although, water is inherently heterogeneous about many properties and pollutants, however, in the case of heavy metals such as $\mathrm{Pb}$, AAS is capable of detecting them at relatively low concentrations. Therefore, the techniques provide a rapid quantitative determination of 'total' elemental concentrations with maximum analytical accuracy, precision (reproducibility) and overall sensitivity. The concept of AAS began with the observation of spectral lines in the sun by Fraunhofer in 1814 and in 1859; Kirchhoff and Bunsen established the key principle that 'Matter absorbs light at the same wavelength at which it emits light' (Alloway, 1995; Alloway and Ayres, 1997; Havrilla, 1997). Although, atomic absorption was first used by Woodson in 1939 however, the basis of the AAS application in recent times is based on work by Walsh in 1955, who showed that metal ions could be reduced to metal atoms in flames; this led to widespread use towards the end of the next decade. ${ }^{8}$ Since then the use of AA spectrometers has expanded rapidly and with the introduction in 1970 of the plasma source there has been an increase in the related method of ICP-AES (Hewitt, 1991; Slavin, 1992; Lajunen, 1992; Alloway, 1995; Manly, 1995; Maskall et al., 1995; Alloway and Ayres, 1997). The production of positive ions in the plasma allows their identification even though interfering ions may be produced in the plasma (Alloway, 1995).

Determination of heavy metal (Fe, $\mathrm{Hg}, \mathrm{Fe}, \mathrm{Zn}$. As, $\mathrm{Mn}$ ) concentrations

The determination of heavy metals in the water samples was done by the atomic absorption spectrophotometry (AAS), according to James (1995). The instrument (Perkin Elmer 6001 AAS) was set up as described in the manufacturer's instrument manual. Using the appropriate element, the hollow-cathode lamp, the monochrometer was set at the selected wavelength, example 324-325nm for copper $(\mathrm{Cu})$. Standard solutions of the different elements of interest were prepared separately. The instrument was zeroed with distilled deionized water. The water samples for this analysis were subjected to acid digestion and subsequently the different mineral elements were determined using appropriate methods as described below by James (1995). The blank, standards and sample digests were run in turns and their readings recorded. Those of the standards were plotted and the curve was used to extrapolate the quantity of the test element. The above procedure was repeated for each test element using the corresponding hollow-cathode lamp and at their various wavelengths.

\section{Digestion}

$10 \mathrm{~mL}$ volume of each water sample was dispensed into an evaporation dish and treated with $15 \mathrm{~mL}$ of concentrated $\mathrm{HNO}_{3}$. The mixture was evaporated to 50 
$\mathrm{mL}$ on a water bath and transferred quantitatively to $100 \mathrm{~mL}$ standard volumetric flask. It was made up to volume with deionized water.

\section{Quality control}

Proper care was taken to minimize random errors during measuring of volumes, temperature taking, and timing. Precision (or reproducibility) was determined by the measurements and analyses of duplicates of samples under the same conditions and within batches. Systematic errors (sampling and sampling preparation, the analytical method, faulty instrumentation, operational mistakes) were avoided to minimize bias. In addition, to avoid these systematic errors, standard references were used in the analytical interpretations. The instrument was operated well above the detection limit. Hence, the AAS was calibrated from 0-100 ppm for metals as found analytically useful for quality control maintenance.

Linear calibration curve (Lambert-Beer Law) will be obtained by plotting absorbance against a series of samples of known concentration from which the concentrations of heavy metals were read-off (Alloway and Ayres, 1997). The final concentration values for all test samples were then derived by taking into account the concentration of the analytes in the blank samples and deducting the values from the overall concentration values in the techniques.

\section{RESULTS}

Seasonal variation in heavy metals biosorption by nine species of bacteria (bacillus, pseudomonas, E.coli, staphylococcus, klebsiella, S. pyogenes, salmonella, and proteus) Isolated in soap and brewery industrial effluent samples from collection zones and a control sites within Aba is reported. The graphical representation of isolated bacteria concentrations in brewery, soap, and control water samples is shown in Fig. 1. The samples were randomly collected and analyzed for $\mathrm{Pb}, \mathrm{Hg}, \mathrm{Fe}, \mathrm{Zn}$, As, and Mn, using atomic absorption spectrophotometry. Levels from the industrial effluents were higher than those from the control samples. Runoff water around the two industries were also contaminated as a result of continuous spatial dispersion of contaminated effluents and probably from the domestic waste dumped into the river. The results also, showed that during rainy and dry seasons, heavy metals are detected albeit at different concentrations with $\mathrm{Fe}$ and $\mathrm{Zn}$ having the highest values of as shown in Tables 1 and 2 for the rainy and dry seasons respectively. Statistical analysis was done using analysis of variance (ANOVA) showed significant differences in concentrations $\mathrm{Pb}, \mathrm{Hg}$, Fe, Zn, As, and Mn level between the sampling zones at Eziama River. The difference in the mean concentrations of metals between sample sites in the rainy season and dry seasons was significant $(\mathrm{P}<0.05)$.

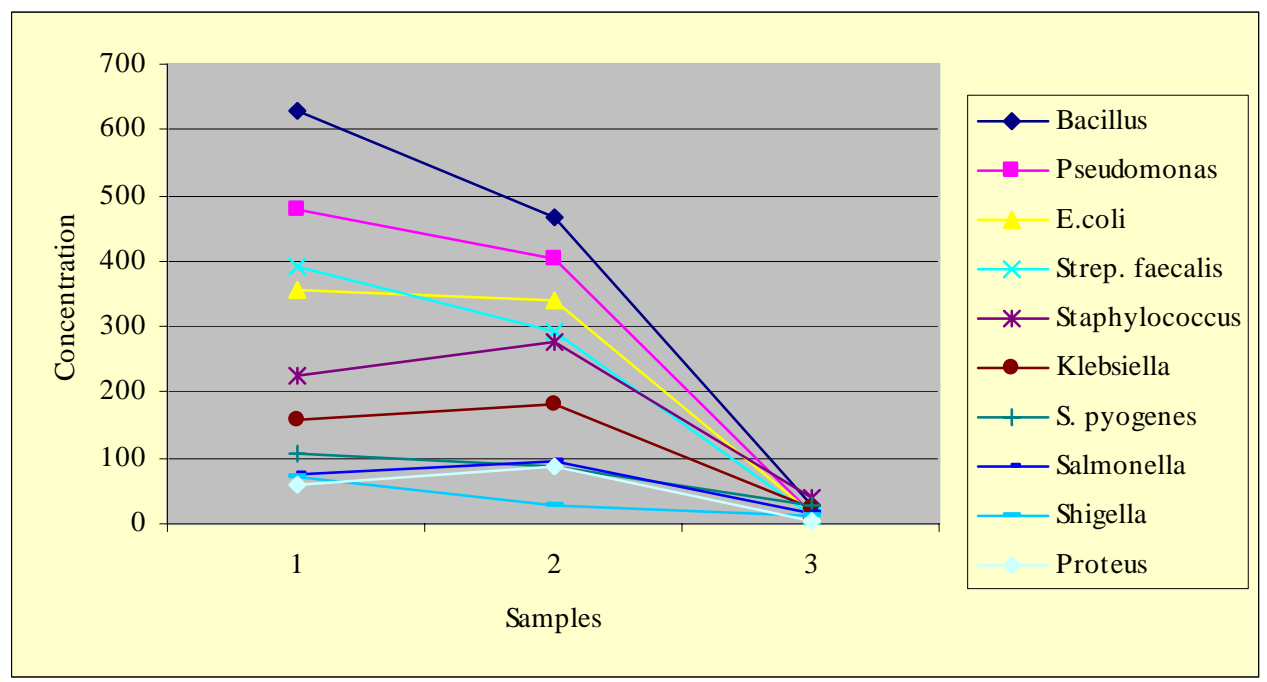

Fig. 1: Graphical representation of isolated bacteria concentrations in brewery, soap, and control water samples 
Table 1: Concentrations of heavy metals in different samples during rainy season

\begin{tabular}{ccccccc}
\hline $\begin{array}{c}\text { Rainy season } \\
\text { sample }\end{array}$ & $\mathrm{Pb}$ & $\mathrm{Hg}$ & $\mathrm{Fe}$ & $\mathrm{Zn}$ & $\mathrm{As}$ & $\mathrm{Mn}$ \\
\hline 1 & 0.06 & $\mathrm{Nil}$ & 0.82 & 2.64 & $\mathrm{Nil}$ & 0.012 \\
2 & 0.06 & $\mathrm{Nil}$ & 0.42 & 0.92 & $\mathrm{Nil}$ & $\mathrm{Nil}$ \\
3 & 0.18 & 0.06 & 3.42 & 3.94 & 0.16 & 0.08 \\
4 & 0.04 & 0.04 & 1.84 & 1.14 & $\mathrm{Nil}$ & 0.36 \\
5 & 0.04 & 0.04 & 1.91 & 1.06 & 0.06 & 0.14 \\
6 & 0.12 & 0.12 & 3.12 & 4.12 & 0.08 & 0.32 \\
7 & $\mathrm{Nil}$ & $\mathrm{Nil}$ & 2.16 & 2.14 & $\mathrm{Nil}$ & 0.26 \\
8 & 0.04 & 0.04 & 1.14 & 2.06 & $\mathrm{Nil}$ & 1.1 \\
9 & 0.08 & 0.08 & 2.66 & 2.86 & 0.12 & 0.12 \\
10 & $\mathrm{Nil}$ & 0.28 & 0.44 & 0.86 & $\mathrm{Nil}$ & 0.22 \\
11 & 0.06 & 0.06 & 0.22 & 0.48 & 0.12 & 0.28 \\
12 & 0.08 & 0.08 & 0.48 & 2.44 & 0.12 & 0.18 \\
$\mathrm{BAF}$ & 0.12 & 0.34 & 8.14 & 3.94 & 0.42 & 0.24 \\
$\mathrm{BBF}$ & 0.2 & 0.29 & 12 & 5.5 & 0.5 & 0.18 \\
PZ & 0.16 & 0.22 & 4.88 & 6.44 & 0.62 & 0.36 \\
Total & 1.32 & 1.65 & 40.35 & 40.54 & 2.32 & 3.99 \\
\hline
\end{tabular}

Table 2: Concentrations of heavy metals in different samples during dry season

\begin{tabular}{ccccccc}
\hline $\begin{array}{c}\text { Dry season } \\
\text { sample }\end{array}$ & $\mathrm{Pb}$ & $\mathrm{Hg}$ & $\mathrm{Fe}$ & $\mathrm{Zn}$ & $\mathrm{As}$ & $\mathrm{Mn}$ \\
\hline 1 & 0.08 & $\mathrm{Nil}$ & 0.76 & 3.14 & $\mathrm{Nil}$ & $\mathrm{Nil}$ \\
2 & 0.04 & $\mathrm{Nil}$ & 0.04 & 0.88 & $\mathrm{Nil}$ & 0.04 \\
3 & 0.22 & 0.08 & 4.12 & 3.86 & 0.2 & 0.6 \\
4 & 0.04 & 0.02 & 1.02 & 1.12 & $\mathrm{Nil}$ & 0.04 \\
5 & 0.02 & 0.1 & 1.14 & 1.12 & 0.02 & 0.02 \\
6 & 0.18 & 0.16 & 3.86 & 4.24 & 0.04 & 0.06 \\
7 & $\mathrm{Nil}$ & $\mathrm{Nil}$ & 1.88 & 2.44 & $\mathrm{Nil}$ & $\mathrm{Nil}$ \\
8 & $\mathrm{Nil}$ & $\mathrm{Nil}$ & 0.84 & 1.62 & 0.12 & Nil \\
9 & 0.04 & $\mathrm{Nil}$ & 2.12 & 3.06 & 0.18 & 0.02 \\
10 & 0.04 & $\mathrm{Nil}$ & 0.48 & 1.14 & $\mathrm{Nil}$ & $\mathrm{Nil}$ \\
11 & 0.1 & 0.02 & 0.16 & 0.38 & 0.16 & 0.04 \\
12 & 0.18 & 0.04 & 0.66 & 2.9 & 0.22 & 0.04 \\
$\mathrm{BAF}$ & 0.12 & 0.04 & 8.14 & 3.94 & 0.42 & 0.08 \\
BBF & 0.2 & 0.14 & 12 & 5.4 & 0.5 & 0.02 \\
PZ & 0.16 & 0.02 & 4.88 & 6.44 & 0.62 & 0.08 \\
Total & 1.42 & 0.62 & 42.1 & 39.24 & 2.48 & 0.98 \\
\hline
\end{tabular}

These zonal differences were due to limited water exchange between the zones of the river. The concentrations of heavy metals Fe and Zn were relatively high and no trends were observed other samples. Comparing the seasonal changes in heavy metal concentrations (Figs. 1 and 2), it is found that $\mathrm{Pb}, \mathrm{Fe}$, and As increased from $1.32 \times 10^{5} \mathrm{mg} / \mathrm{L}$ in the rainy season to $1.42 \times 10^{5} \mathrm{mg} / \mathrm{L}$ in the dry season (Table $3)$. This is significant in terms of risks between the seasons. Fe increased from 40.35 x $10^{5} \mathrm{mg} / \mathrm{L}$ to $42.1 \mathrm{x}$ $10^{5} \mathrm{mg} / \mathrm{L}$, while As increased from 2.32 to $2.48 \times 10^{5} \mathrm{mg} /$ $\mathrm{L}$ with a net increases of +56 and $+69 \times 10^{5} \mathrm{mg} / \mathrm{L}$ respectively. However, $\mathrm{Hg}, \mathrm{Zn}$, and Mn concentrations decreased in the rainy season from $40.54 \times 10^{5} \mathrm{mg} / \mathrm{L}$ to $39.24 \times 10^{5} \mathrm{mg} / \mathrm{L}, 1.65$ to $0.62 \times 10^{5} \mathrm{mg} / \mathrm{L}$ by a huge net amount of $-62 \times 10^{5} \mathrm{mg} / \mathrm{L} .,-32$ and $-75 \times 10^{5} \mathrm{mg} / \mathrm{L}$ respectively. Except for zinc and iron, the concentrations of the other heavy metals were within the relatively low. The high concentrations of Fe and $\mathrm{Zn}$ may be due to domestic waste and brewery and soap industrial discharges into the Eziama River.

\section{DISCUSSION AND CONLUSION}

The result findings for a range of heavy metal concentrations using AAS techniques are presented accordingly. The AAS analyses of the effluent water 
Table 3: Over all \% heavy metal increase or decrease between rainy and dry seasons

\begin{tabular}{ccccccc}
\hline & \multicolumn{7}{c}{ Heavy metals $(\mathrm{X} \mathrm{10}$ mg/L) } \\
\hline Metals & $\mathrm{Pb}$ & $\mathrm{Hg}$ & $\mathrm{Fe}$ & $\mathrm{Zn}$ & $\mathrm{As}$ & $\mathrm{Mn}$ \\
Rainy season values & 1.32 & 1.65 & 40.35 & 40.54 & 2.32 & 3.99 \\
Dry season values & 1.42 & 0.62 & 42.1 & 39.24 & 2.48 & 0.98 \\
\% Decrease/increase & +8 & -62 & +5.6 & -3.2 & +6.9 & -75 \\
\hline
\end{tabular}

concentrations are compared to the respective concentrations. One would suspect that the difference would most likely be due to systematic errors arising during sampling, preparation, dilution and injection of sample or due to random errors caused by method such as weighing, measuring volumes, temperature, humidity and time (Alloway, 1995). Since the duplicate values from the test samples and the 'standard reference samples' are consistent in techniques, therefore the results are accurate and reproducible. Results obtained showed that the rate of accumulation of these heavy metals varied among the samples examined. In all the samples examined, some recorded the lowest level of heavy metals. Overall, seasonal variation of these heavy metals showed that rainy season has relatively the highest values for lead, Zinc and Mn compared to other metals for dry season. The concentrations of heavy metals were also, generally low in some samples and no similar trends were observed in the control samples. Except for iron and zinc, the concentrations of the other heavy metals were relatively low. The low concentrations of these particular heavy metals may be due to spatial dilution along the Eziama River. The results showed that during rainy and dry seasons, most heavy metals under study were detected in all the samples albeit at different concentrations with $\mathrm{Fe}$ (40.35 $\mathrm{x} 10^{5} \mathrm{mg} / \mathrm{L}$ to $42.1 \times 10^{5} \mathrm{mg} / \mathrm{L}$ in rainy and dry season respectively) and $\mathrm{Zn}\left(40.54 \times 10^{5} \mathrm{mg} / \mathrm{L}\right.$ to $39.24 \times 10^{5}$ $\mathrm{mg} / \mathrm{L}$ in rainy and dry season respectively) having the highest values. There were significant differences in concentrations $\mathrm{Pb}, \mathrm{Hg}, \mathrm{Fe}, \mathrm{Zn}$, As, and $\mathrm{Mn}$ level between the sampling zones at Eziama River. These zonal differences could be due to limited water exchange between the zones of the river. The concentrations of heavy metals $\mathrm{Fe}$ and $\mathrm{Zn}$ were relatively high and no serious trends were observed in other samples. The high concentrations of $\mathrm{Fe}$ and $\mathrm{Zn}$ may be due to brewery and soap industrial discharges into the Eziama River. Comparing the seasonal changes in heavy metal concentrations of $\mathrm{Pb}, \mathrm{Fe}$, and As increased from $1.32 \mathrm{x}$ $10^{5} \mathrm{mg} / \mathrm{L}$ in the rainy season to $1.42 \times 10^{5} \mathrm{mg} / \mathrm{L}$ in the dry season. This is significant in terms of risks between the seasons. Fe increased from $40.35 \times 10^{5} \mathrm{mg} / \mathrm{L}$ to 42.1 $\mathrm{x} 10^{5} \mathrm{mg} / \mathrm{L}$, while As increased from 2.32 to $2.48 \times 10^{5}$ $\mathrm{mg} / \mathrm{L}$ with a net increases of +56 and $+69 \times 10^{5} \mathrm{mg} / \mathrm{L}$ respectively. However, $\mathrm{Hg}$, $\mathrm{Zn}$ and $\mathrm{Mn}$ concentrations decreased in the rainy season from $40.54 \times 10^{5} \mathrm{mg} / \mathrm{L}$ to $39.24 \times 10^{5} \mathrm{mg} / \mathrm{L}, 1.65$ to $0.62 \times 10^{5} \mathrm{mg} / \mathrm{L}$ by a huge net amount of $-62 \times 10^{5} \mathrm{mg} / \mathrm{L} .,-32$ and $-75 \times 10^{5} \mathrm{mg} / \mathrm{L}$ respectively. These results are consistent with similar studies (Odokuma and Abah, 2003) from the New Calabar River but varied greatly in the sources and levels of heavy metal concentrations obtained. For example, New Calabar River water ranges were: $\mathrm{Pb}(0.01$ to $0.02 \mathrm{mg} / \mathrm{L})$, and $\mathrm{Zn}(0.01$ to $0.07 \mathrm{mg} / \mathrm{L})$. Sediment heavy metal ranges were $\mathrm{Cu}(1.09$ to $1.45 \mathrm{mg} / \mathrm{L}), \mathrm{Pb}$ ( 0.03 to $0.07 \mathrm{mg} / \mathrm{L})$. The ease of bioaccumulation of the metals by bacteria showed the following trend $>\mathrm{Fe}$ $>\mathrm{Zn}>\mathrm{As}>\mathrm{Pb}>\mathrm{Mn}$ (Rainy Season) and $\mathrm{Zn}>\mathrm{Fe}>\mathrm{Mn}$ $>\mathrm{As}>\mathrm{Hg}>\mathrm{Pb}$. These metals are very toxic to the bacteria. Lead and Zinc displayed similar levels of toxicity.

\section{Environmental health implications}

Although, these trace metals differ widely in their chemical properties, their relative concentrations and discharges and hence, their bioavailability are very important to terrestrial, aquatic and marine organisms in terms of toxicity (Alloway and Ayres, 1997). These emissions often result in extensive and persistent contamination of water, vegetation (Waldron, 1980; Fergusson, 1990). The overall effects of the resultant emissions on the living organisms including animals and humans are many and often life threatening. One would suggest that no matter the factor and level of exposure (occupational and environmental) to heavy metal contamination, children are directly or indirectly the most vulnerable. They could be affected through contaminated food, milk, and contact or even through developmental processes. Lead is known to be a neurotoxicant since antiquity. The link between human exposures to $\mathrm{Pb}$ has been firmly established (OTA, 1990; Anger et al., 1996). The role of $\mathrm{Pb}$ as a childhood toxicant is also known for nearly a hundred years. Public concern over this issue has been considerable; parents are justifiably upset to learn that an avoidable 
exposure might result in deleterious neurobehavioral effects too subtle to be obvious in daily life but potentially important to a child's long-term health, quality of life, and intelligence (Anger, 1984; Anger, 1986; Muldoon et al., 1996). Lead is known to produce developmental neurotoxicity and it has been shown that infants and children may be differentially sensitive to environmental $\mathrm{Pb}$ exposure. Exposure during development can result in a spectrum of defects, including structural abnormalities, altered growth, and functional deficits, sexual maturity and consequently, death (Dolk et al., 1988; Geschwind et al., 1992; Shaw et al., 1993; Mitchell et al., 1996; Needham, 1996; Johnson, 1997). The link between low-level lead exposure and deficits in IQ, neurobehavioral development and physical growth is remarkably consistent without exception. People exposed to toxic chemicals especially $\mathrm{Pb}$, whether through occupation or residential homes, manifest similar symptoms of neurotoxicity. Hanninen et al., (1979) suggested that subjective symptoms of a neurovegetative nature constitute the first response to low-level exposure to neurotoxicants. Mood disturbance, headache, lowgrade nausea, fatigue, and other symptoms are often reported by workers and community residents exposed to low concentrations of specific neurotoxicants.

\section{Water contamination}

If there is a river near the disused industrial site, the possibility of that river being contaminated by $\mathrm{Pb}$ is great. That was probably why such rivers have significant concentrations of $\mathrm{Pb}$ in their sediments. For example, Murray (1996) compared heavy metal concentrations using statistical t tests to determine $\mathrm{Pb}, \mathrm{Cu}$, and chromium enrichment in sediments from the lower branch of the Rouge river in southeast Michigan, USA. Both absolute metal concentrations and ratios of trace metal to conservative metal concentrations were used to compare sampled sites along the river to background sites in the headwaters region. Concentration ratios were used to reduce the effects of certain chemical and physical characteristics on the level of metal contained in given sediment. Results from the comparison of sample sites to the background revealed metal enrichment at several sites, particularly along the highly urbanized, downstream section of the river. This section of the Lower Branch of the Rouge River exhibits significant lead and copper contamination, as well as measurable chromium enrichment when using either concentrations alone or ratios as methods of comparison. The areas of metal enrichment appear to coincide closely with areas of known anthropogenic activities. Of particular interest, however, is the enrichment of lead and copper at two upstream sites where the statistical tests suggest an anthropogenic source for the enrichment, but where no previously known cultural activities existed. These data prompted a historical search of records, which discovered several abandoned industrial landfills immediately upstream of the metal enrichment sites (Murray, 1996).

\section{Food contamination}

Heavy metal contamination persists and migrates in the water. If food crops are planted in near the river it is possible for the metal contaminants to be transferred to the food crops. Adverse health effects of water $\mathrm{Hg}, \mathrm{Zn}$ and $\mathrm{Pb}$ have led to public health concern hence, Dudka et al., (1996) conducted a 4-year field experiment to study the transfer of $\mathrm{Cd}, \mathrm{Pb}$, and $\mathrm{Zn}$ between media (water, soil and air) and found highest metal concentrations in potato tubers (intact), meadow bluegrass, and barley straw. Often, the information describing the health impact of the susceptibility factor is incomplete due to, (i) a failure to consider factors modifying susceptibility; (ii) inadequate exposure data; (iii) a failure to evaluate the health impact of the susceptibility factor (Johnson, 1997). In addition, for a given exposure agent, several susceptibility factors may be relevant (Grassman, 1996). While incomplete data describing susceptibility factors limits the opportunity for quantitative estimations of risk, information from soil analysis can supplement qualitative evaluations and risk prevention and management.

The heavy metal concentrations in industrial effluents discharged into the Eziama River have been determined using AAS techniques. It has been demonstrated that the techniques are sensitive, accurate, and reliable and may be useful in analyzing the levels of heavy metal contamination in river located near industrial sites. Rivers near industrial sites are never free from heavy metal contamination no matter the type of industry and the products produced. Environmental health exposures to toxic chemicals such as $\mathrm{Pb}, \mathrm{Hg}, \mathrm{Fe}, \mathrm{Zn}$, As, and Mn contained in such industrial effluents without doubts have the potential to cause harm. Therefore, it is important that if such rivers near 
industrial manufacturing should be monitored and be adequately treated for residential uses. Bioaccumulation potentials of the nine bacteria indicated that Bacillus showed the highest potential this was followed by Staphylococcus while Pseudomonas showed the least potential. These results indicate that bacteria especially Bacillus may be employed in the bioremoval of heavy metals from tropical aquatic environments impacted with heavy metals.

\section{REFERENCES}

Agedengbe, K., Akinwole, A. O. and Babatunde, A. O., (2003). Effluents characteristics of selected industries in western Nigeria and implications for re-use in agricultural production. J. Environ. Exten., 4, 79-82.

Alloway, B. J., (1995). (Ed.) Heavy metals in soils $2^{\text {nd. }}$ Ed., Ch. 2. Blackie and Sons, Glasgow.

Alloway, B. J. and Ayres, D. Z., (1997). In Chemical Principles of Environmental Pollution $2^{\text {nd. }}$ Ed., Ch. 5. Blackie Academic \& Professional, London.

Anger, W. K., (1984). Neurobehavioural testing of chemicals: impact on recomended standards. Neurobehav Toxic. Terat., 6, 147-153.

Anger, W. K., (1986). Workplace exposures. In: Annau, ZA, ed., Neurobehavioural toxicology. Baltimore: Johns Hopkins University Press, 331-347.

Anger, W. K., Otto, D. A. and Letz, R., (1996). (Eds) Symposium on computerized behavioural testing of humans in neurotoxicology research. Neurotoxic. Terat., 18, 347-518.

Anonymous, OTA (Office of Technology Assessment). 1990. Neurotoxicity: Identifying and controlling poisons of nervous system. OTA Publication No. OTA-BA, Washington: US Government Printing Office.

Barnes, R. S. K., (2004). The distribution and habitat in the Knysna Estuary of the endemic South African mudsnail Hydrobia knysnaensis and the influence of intraspecific competition and ambient salinity on its abundance. African J. Aqua. Sci., 29 (2), 205-211.

Dallas, H. F., (2004). Spatial variability in macroinvertebrate assemblages: comparing regional and multivariate approaches for classifying reference sites in South Africa. African J. Aqua. Sci., 29 (2), 161-71

Dolk, H., Vrijheid, M., Armstrong, B., Abramsky, L., Bianchi, F., Garne, E., Nelen, V., Robert, E., Scott JES, Stone, D. and Tenconi, R., (1988)., Risk of congenital anomalies near hazardous-waste landfill sites in Europe: the Eurohazcon study. Lancet, 352, 423-27.

Dudka, S., Piotrowska, M. and Terelak, H., (1996)., Transfer of cadmium, lead, and zinc from industrially contaminated soil to crop plants: A field study. Environ Pollut., 94 (2): 181-188.

El-Gohary, F. A., Abo-Elela, S. I. and Ali, H. I., (1987)., Management of wastewater from soap and food industries: a case study. Sci Total Environ., 66, 203-12.
Fergusson, J. E., (1990)., The Heavy Elements: Chemistry, Environmental Impact and Health Effects. Pergamon Press, Oxford.

Geschwind, S, Stolwijk, J., Bracken, M., (1992). Risk of congenital malformations associated with proximity to hazardous waste sites. Am J Epidemiol., 135, 1197-207.

Grassman, J. A., (1996)., Obtaining information about susceptibility from the epidemiological literature. Toxic., 3, (1-3), 253-270.

Hanninen, H., Mantere, P., Hernberg, S., Seppalainen, A., and Kock, B. (1979). Subjective symptoms in low-level exposure to lead. Neurotoxic., 1, 333-348.

Havrilla, G. J., (1997). Handbook of Instrumental Techniques for Analytical Chemistry Frank Settle, Editor: XRayFluorescence Spectrometry,Prentice Hall.

Hewitt, C. N., (1991). (Ed.) Instrument Analysis of Pollutants. Elsevier, London.

Johnson, B. L., (1997). Hazardous Waste: Human Health Effects. Toxicol Industr Health., 13 (2-3), 121-43.

Johnson, B. L., (1997). Hazardous Waste: Human Health Effects. Toxic. Ind. Health., 13 (2-3), 121-43.

Lajunen, L. H. J., (1992). Spectrochemical Analysis by Atomic Absorption and Emission. Royal Society of Chemistry, Cambridge.

Lajunen, L. H. J., (1992). Spectrochemical Analysis by Atomic Absorption and Emission, Royal Society of Chemistry.

Manly, R., (1995). In Environmental Analytical Chemistry, Ch. 12. (eds. F.W. Fifield and P.J. Hains). 249-79. Blackie $A$ and $P$, Glasgow.

Maskall, J., Whitehead, K. and Thornton, I., (1995). Heavy metal migration in soils and rocks at historical smelting sites. Environ. Geochem. Health, 17, 127-38.

Mitchell, C. S., Shear, M. S., Bolla, K. I. and Schwartz, B.S., (1996). Clinical evaluation of 58 organolead manufacturing workers. J. Occu. Environ. Med., 38 (4), 372-378.

Muldoon, S. B., Cauley, J. A., Kuller, L. H., Morrow, L., Needleman, H. L., Scott, J. and Hooper, F. J., (1996). Effects of blood lead levels on cognitive function of older women. Neuroepid., 15 (2), 62-72.

Murray, K. S., (1996). Statistical comparisons of heavy metal concentrations in river sediments. Environ Geol, 27 (1), 54-58.

Needham, L. L., (1996). Proposed use of human exposure biomarkers in environmental legislation: Toxic substances control act. ACS Symposium Series, 643, 24-38

Odokuma, L. O. and Abah, A. E., (2003). Heavy metal biosorption by three bacteria isolated from a tropical river. Global. J. Environ. Sci., 2 (2), 98-101.

Shaw, G., Schulman, J., Frisch, J. D, Cummins, S. K. and Harris, J. A., (1993). Congenital malformations and birthweight in areas with potential environmental contamination. Arch. Environ. Health., 47, 147-54.

Slavin, W., (1992). A comparison of atomic spectroscopic analytical techniques. Spec. Intern., 22-7.

Waldron, H. A., (1980). (Ed.) In Metals in the Environment, Ch. 6. Academic Press, London. 


\section{AUTHOR(S) BIOSKETCHES}

Kanu, I., Department of Microbiology, Abia State University, Abia State, Nigeria,

E-mail: ijay2001kay@yahoo.com

Achi, O. K., Department of Industrial Microbiology, The Michael Okpara Federal University of Agriculture, Umudike, Umuahia, Abia State, Nigeria. E-mail: omekachi@yahoo.com

Ezeronye, O. U., Department of Industrial Microbiology, The Michael Okpara Federal University of Agriculture, Umudike, Umuahia, Abia State, Nigeria. E-mail: ezeronyeob@yahoo.com

Anyanwu, E. C., Department of Chemistry, Environmental Toxicology Program, Texas Southern University, Houston, Texas, USA. E-mail: ebereanyanwu@yahoo.com

\section{This article should be referenced as follows:}

Kanu, I., Achi, O. K., Ezeronye, O. U. and Anyanwu E. C., (2006). Seasonal variation in bacterial heavy metal biosorption in water samples from Eziama river near soap and brewery industries and the environmental health implications. Int. J. Environ. Sci. Tech., 3 (1), 95-102. 